\title{
Insights into maternal diet for the prevention of childhood leukaemia
}

Catia Daniela Cantarella ${ }^{1}$, Denise Ragusa ${ }^{2}$ and Sabrina Tosi ${ }^{2 *}$

*Correspondence: Sabrina.tosi@brunel.ac.uk

${ }^{1}$ Via Trento 11, Santa Venerina, CT, Italy.

${ }^{2}$ Leukaemia and Chromosome Research Laboratory, Division of Biosciences, College of Health and Life Sciences, Institute of Environment, Health and Societies, Brunel University London, UK.

\begin{abstract}
Nutrition plays a crucial role in wellbeing and is being increasingly recognised as an environmental factor in the development of disease. During pregnancy, maternal diet influences foetal development, playing a role not only in the prevention of neural tube defects and malformations, but also in the susceptibility to disease later in life. Certain micronutrients, such as folates, are involved in the maintenance of genome integrity, which is compromised in cancer. A deficiency in these nutrients can therefore be relevant in carcinogenic processes. The early onset of childhood leukaemia implies that it originates already in utero, where environmental factors can interfere with the healthy development of the foetus. Population studies have found an association between maternal intake of folic acid and multivitamins and a reduced risk in the development of leukaemia in the offspring. Although the supplementation of vitamins is recommended during pregnancy, the adequate dosage and nutrient combinations need to be further elucidated to fully maximise their protective role.
\end{abstract}

Keywords: Leukaemia, childhood leukaemia, childhood cancer, nutrition, pregnancy, folate, diet, micronutrients

\section{Introduction}

Childhood leukaemia is a rare form of cancer affecting approximately 1700 children a year in the UK [1], accounting for one third of all childhood malignancies [2]. The prognostic profile varies by subtype, with some groups having extremely poor clinical outcomes. Despite the improvements in treatment options and overall survival, leukaemia still detains high mortality rates, affecting very young children, even before their first birthday. It is now broadly accepted that infant leukaemia has a prenatal origin. This statement is based on scientific evidence derived from the study of neonatal blood spots from archival Guthrie cards, showing the presence of the genetic rearrangements typically associated with infant leukaemia at this early stage of life [3]. These rearrangements only appear in the blood cell precursors responsible for the disease and are not inherited from the parents. What is then the cause of such genetic defects in the developing foetus? The culprit might be found among environmental factors that influence foetal life since conception, or even prior to conception.

\section{Main body}

The exact aetiology of the disease is still obscure, although a number of environmental factors such as exposure to harmful chemicals and infection have been identified [4]. Many exogenous factors are capable of inducing genetic and epigenetic changes such as DNA methylation status, which is known to be altered in cancer including childhood leukaemia. While certain factors such as prenatal exposure to radiation, smoking and carcinogenic chemicals are strongly associated with the risk of acute lymphoblastic leukaemia (ALL), the role of other substances such as iron, caffeine, and common household chemicals remains unclear [5].

Nutrition and maternal diet are gaining an increasingly important role as environmental factors capable of interfering with genome integrity, with micronutrients detaining a major role in the development of the foetus. Folates and other vitamins of the B family, for instance, are involved in the biochemical reactions required for DNA synthesis, DNA methylation and DNA repair pathways [6]. Folic acid supplementation during 
pregnancy has now been recommended for many years for the prevention of neural tube defects. A complete vitamin and mineral supplementation, including iron, calcium, vitamin $D$, and vitamin $\mathrm{B} 12$, are also recommended during pregnancy to ensure the wellbeing of both mother and child [7]. An appropriate vitamin supplementation prior to conception is also recommended to prepare healthy gametes and to prevent chromosomal non-disjunction, which are responsible for the formation of aneuploidies in the foetus, hence to prevent genetic disorders (e.g. Down syndrome) and malformations [8].

In contrast, so far little attention has been drawn to the importance of maternal diet and vitamin supplementation in the prevention of childhood cancer. Emerging scientific evidence has shown that consumption of folic acid and multivitamin supplements reduces the risk of leukaemia in the offspring. Despite some contradiction in population studies [9-13], recent publications suggest that folic acid does play a protective role against these malignancies, with varying results on specific subtypes. Altobelli et al. [14] showed that a reduced intake of protein during pregnancy was associated with changes in methylation patterns of DNA, which could be reversed upon folic acid supplementation. Another study [15] investigated the role of maternal diet as a potential risk for $A L L$, reporting that a diet rich in fruit, vegetable and protein before and during pregnancy is capable of reducing the risk of ALL in the offspring. A reduced risk of ALL was also associated with consumption of food items from the Mediterranean diet (fruit, vegetables, fish and legumes) together with supplementation of folic acid and multivitamins prior to conception [16]. Thomopoulos et al. [17] found a correlation between the consumption of coffee and an increased risk of childhood leukaemia. Similar results were found for the consumption of cola. Tea was proved to have an inverse effect, probably due to the protective action of micronutrients that counteracted the harmful effects of caffeine. In contrast, limited studies are available on the risk of acute myeloid leukaemia (AML), with most authors finding weak associations between maternal diet and AML in the offspring [11].

Most studies have focused on the role of polymorphisms of genes involved in folate metabolism in influencing the risk of $A L L$ and $A M L$, with contradicting results attributable to the genetic diversity among different populations. In general, the susceptibility due to genetic polymorphisms seems to be more evident for ALL than AML $[\mathbf{9}, \mathbf{1 8 - 2 0}]$, with few exceptions such as the Romanian population that seems to be particularly at risk for the development of AML in the presence of polymorphic variants of the MTHFR gene [21,22]. Some authors, however, found no correlation [23-25].

The current dosage recommendations have been disputed due to concerns regarding unmetabolised folic acid being observed in circulation above $200 \mu \mathrm{g} /$ day [26]. As excessive folic acid intake has been linked with the adverse effect of nourishing existing cancerous or pre-cancerous lesions, the long-term implications of unmetabolised folic acid need to be further elucidated [27]. In order to maximise the protective role of folic acid, the optimal dosage ranges need to be revisited. It is also important to draw a distinction between folates and folic acid, the latter being the synthetic form. Food fortification and dietary supplements contain folic acid, which is not metabolised as efficiently as the natural folate. An excessive intake of synthetic folic acid can mask a vitamin B12 deficiency in the mother, potentially leading to jaundice in the newborn [28].

\section{Conclusion}

Population studies have highlighted the importance of maternal diet and vitamin supplementation before and during pregnancy, with particular focus on the protective effects against childhood leukaemia and other cancers. Further research is needed to uncover the interactions between macro- and micronutrients and their effects on the genome, with the ultimate goal of establishing correct combinations and dosage. When prescribing vitamin supplementation, practitioners should be mindful of current research in the field and recommend diets rich in natural sources of vitamins and micronutrients, first and foremost vegetables, fruit and legumes, in view of preventing a wide range of health concerns. It is becoming increasingly apparent that the protective role of micronutrients is maximised when the maternal diet is viewed as a whole, rather than focusing on single nutrients. Broadly speaking, maternal diet is not only important to ensure the health and wellbeing of the new-born, but to minimise the likelihood of developing pathologies, including cancer and particularly leukaemia, throughout childhood and later in life.

\section{List of abbreviations}

ALL: Acute lymphoblastic leukaemia

AML: Acute myeloid leukaemia

\section{Competing interests}

The authors declare that they have no competing interests.

Authors' contributions

\begin{tabular}{|l|c|c|c|}
\hline Authors' contributions & CDC & DR & ST \\
\hline Research concept and design & $\checkmark$ & -- & $\checkmark$ \\
\hline Collection and/or assembly of data & $\checkmark$ & $\checkmark$ & -- \\
\hline Data analysis and interpretation & $\checkmark$ & $\checkmark$ & -- \\
\hline Writing the article & $\checkmark$ & $\checkmark$ & $\checkmark$ \\
\hline Critical revision of the article & -- & -- & $\checkmark$ \\
\hline Final approval of article & $\checkmark$ & $\checkmark$ & $\checkmark$ \\
\hline Statistical analysis & -- & -- & -- \\
\hline
\end{tabular}

\section{Publication history}

EIC: Evangelos Terpos, University of Athens School of Medicine, Greece. Received: 27-Oct-2017 Final Revised: 15-Dec-2017

Accepted: 30-Dec-2017 Published: 12-Jan-2018 


\section{References}

1. Cancer Research UK. Children's cancers incidence statistics. 2017 | Website

2. Steliarova-Foucher E, Colombet M, Ries LAG, Moreno F, Dolya A, Bray F, Hesseling P, Shin HY and Stiller CA. International incidence of childhood cancer, 2001-10: a population-based registry study. Lancet Oncol. 2017; 18:719-731. | Article | PubMed Abstract | PubMed FullText

3. Wiemels JL, Cazzaniga G, Daniotti M, Eden OB, Addison GM, Masera G, Saha V, Biondi A and Greaves MF. Prenatal origin of acute lymphoblastic leukaemia in children. Lancet. 1999; 354:1499-503. | Article | PubMed

4. Wiemels J. New insights into childhood leukemia etiology. Eur J Epidemiol. 2015; 30:1225-7. | Article | PubMed

5. Timms JA, Relton $\mathrm{CL}$, Rankin J, Strathdee $\mathrm{G}$ and McKay JA. DNA methylation as a potential mediator of environmental risks in the development of childhood acute lymphoblastic leukemia. Epigenomics. 2016; 8:519-36. | Article | PubMed Abstract | PubMed FullText

6. Cantarella CD, Ragusa D, Giammanco M and Tosi S. Folate deficiency as predisposing factor for childhood leukaemia: a review of the literature. Genes Nutr. 2017; 12:14. | Article I PubMed Abstract | PubMed FullText

7. Kaiser $\mathrm{L}$ and Allen LH. Position of the American Dietetic Association: nutrition and lifestyle for a healthy pregnancy outcome. J Am Diet Assoc. 2008; 108:553-61. | Article | PubMed

8. Czeizel AE and Puho E. Maternal use of nutritional supplements during the first month of pregnancy and decreased risk of Down's syndrome: case-control study. Nutrition. 2005; 21:698-704; discussion 774. | Article I PubMed

9. Milne E, Royle JA, Miller M, Bower C, de Klerk NH, Bailey HD, van Bockxmeer F, Attia J, Scott RJ, Norris MD, Haber M, Thompson JR, Fritschi L, Marshall GM and Armstrong BK. Maternal folate and other vitamin supplementation during pregnancy and risk of acute lymphoblastic leukemia in the offspring. Int J Cancer. 2010; 126:2690-9. | Article | PubMed

10. Metayer C, Milne E, Dockerty JD, Clavel J, Pombo-de-Oliveira MS, Wesseling C, Spector LG, Schuz J, Petridou E, Ezzat S, Armstrong BK, Rudant J, Koifman S, Kaatsch P, Moschovi M, Rashed WM, Selvin S, McCauley K, Hung RJ, Kang AY and Infante-Rivard C. Maternal supplementation with folic acid and other vitamins and risk of leukemia in offspring: a Childhood Leukemia International Consortium study. Epidemiology. 2014; 25:811-22. | Article | PubMed

11. Singer AW, Selvin S, Block G, Golden C, Carmichael SL and Metayer C. Maternal prenatal intake of one-carbon metabolism nutrients and risk of childhood leukemia. Cancer Causes Control. 2016; 27:929-40. | Article | PubMed Abstract | PubMed FullText

12. Thompson JR, Gerald PF, Willoughby ML and Armstrong BK. Maternal folate supplementation in pregnancy and protection against acute lymphoblastic leukaemia in childhood: a case-control study. Lancet. 2001; 358:1935-40. | Article | PubMed

13. Chokkalingam AP, Chun DS, Noonan EJ, Pfeiffer CM, Zhang M, Month SR, Taggart DR, Wiemels JL, Metayer C and Buffler PA. Blood levels of folate at birth and risk of childhood leukemia. Cancer Epidemiol Biomarkers Prev. 2013; 22:1088-94. | Article | PubMed Abstract | PubMed FullText

14. Altobelli G, Bogdarina IG, Stupka E, Clark AJ and Langley-Evans S. Genome-wide methylation and gene expression changes in newborn rats following maternal protein restriction and reversal by folic acid. PLoS One. 2013; 8:e82989. | Article | PubMed Abstract | PubMed FullText

15. Abiri B, Kelishadi R, Sadeghi H and Azizi-Soleiman F. Effects of Maternal Diet During Pregnancy on the Risk of Childhood Acute Lymphoblastic Leukemia: A Systematic Review. Nutr Cancer. 2016; 68:1065-72. | Article I PubMed

16. Dessypris N, Karalexi MA, Ntouvelis E, Diamantaras AA, Papadakis V, Baka M, Hatzipantelis E, Kourti M, Moschovi M, Polychronopoulou S, Sidi V, Stiakaki E and Petridou ET. Association of maternal and index child's diet with subsequent leukemia risk: A systematic review and meta analysis. Cancer Epidemiol. 2017; 47:64-75. | Article I PubMed

17. Thomopoulos TP, Ntouvelis E, Diamantaras AA, Tzanoudaki M, Baka
M, Hatzipantelis E, Kourti M, Polychronopoulou S, Sidi V, Stiakaki E, Moschovi M, Kantzanou M and Petridou ET. Maternal and childhood consumption of coffee, tea and cola beverages in association with childhood leukemia: a meta-analysis. Cancer Epidemiol. 2015; 39:104759. | Article | PubMed

18. Franco RF, Simoes BP, Tone LG, Gabellini SM, Zago MA and Falcao RP. The methylenetetrahydrofolate reductase $C 677 T$ gene polymorphism decreases the risk of childhood acute lymphocytic leukaemia. $\mathrm{Br} J$ Haematol. 2001; 115:616-8. | Article | PubMed

19. Gemmati D, Ongaro A, Scapoli GL, Della Porta M, Tognazzo S, Serino ML, Di Bona E, Rodeghiero F, Gilli G, Reverberi R, Caruso A, Pasello M, Pellati $A$ and De Mattei M. Common gene polymorphisms in the metabolic folate and methylation pathway and the risk of acute lymphoblastic leukemia and non-Hodgkin's lymphoma in adults. Cancer Epidemiol Biomarkers Prev. 2004; 13:787-94. | Article | PubMed

20. Alcasabas P, Ravindranath Y, Goyette G, Haller A, Del Rosario L, Lesaca-Medina MY, Darga L, Ostrea EM, Jr., Taub JW and Everson RB. 5,10-methylenetetrahydrofolate reductase (MTHFR) polymorphisms and the risk of acute lymphoblastic leukemia (ALL) in Filipino children. Pediatr Blood Cancer. 2008; 51:178-82. I Article | PubMed

21. Banescu C, lancu M, Trifa AP, Macarie I, Dima D and Dobreanu M. The methylenetetrahydrofolate reductase (MTHFR) 677 C>T polymorphism increases the risk of developing chronic myeloid leukemia-a casecontrol study. Tumour Biol. 2015; 36:3101-7. | Article | PubMed

22. Banescu $C$ and Trifa AP. Methylenetetrahydrofolate reductase 677 C> T polymorphism is associated with acute myeloid leukemia. Leuk Lymphoma. 2015; 56:1172-4. | Article | PubMed

23. Chiusolo P, Reddiconto G, Cimino G, Sica S, Fiorini A, Farina G, Vitale A, Sora F, Laurenti L, Bartolozzi F, Fazi P, Mandelli F and Leone G. Methylenetetrahydrofolate reductase genotypes do not play a role in acute lymphoblastic leukemia pathogenesis in the Italian population. Haematologica. 2004; 89:139-44. | Article I PubMed

24. Schnakenberg E, Mehles A, Cario G, Rehe K, Seidemann K, Schlegelberger B, Elsner HA, Welte KH, Schrappe M and Stanulla M. Polymorphisms of methylenetetrahydrofolate reductase (MTHFR) and susceptibility to pediatric acute lymphoblastic leukemia in a German study population. BMC Med Genet. 2005; 6:23. | Article | PubMed Abstract | PubMed FullText

25. Kim HN, Kim YK, Lee IK, Yang DH, Lee JJ, Shin MH, Park KS, Choi JS, Park MR, Jo DY, Won JH, Kwak JY and Kim HJ. Association between polymorphisms of folate-metabolizing enzymes and hematological malignancies. Leuk Res. 2009; 33:82-7. | Article | PubMed

26. Kelly P, McPartlin J, Goggins M, Weir DG and Scott JM. Unmetabolized folic acid in serum: acute studies in subjects consuming fortified food and supplements. Am J Clin Nutr. 1997; 65:1790-5. I Article I PubMed

27. Kim YI. Will mandatory folic acid fortification prevent or promote cancer? Am J Clin Nutr. 2004; 80:1123-8. | Article I PubMed

28. Niknamian $S$ and Zaminpira S. Synthetic Folic Acid Supplementation during Pregnancy Increases the Risk of Neonatal Jaundice in Newborns. JMEST. 2016; 3:6429-31. | Pdf

\section{Citation:}

Cantarella CD, Ragusa D AND Tosi S. Insights into maternal diet for the prevention of childhood leukaemia. Hematol Leuk. 2018; 6:1. http://dx.doi.org/10.7243/2052-434X-6-1 